\title{
Cone-beam computed tomography in Endodontics: an exploratory research of the main clinical applications
}

\author{
Tomografia computadorizada de feixe cônico em Endodontia: uma pesquisa exploratória das \\ principais aplicações clínicas \\ Tomografía computarizada de haz cónico en Endodoncia: una investigación exploratoria de las \\ principales aplicaciones clínicas
}

Received: 01/10/2021 | Reviewed: 01/18/2021 | Accept: 01/18/2021 | Published: 01/22/2021

Priscila de Andrade Cruz Oliveira

ORCID: https://orcid.org/0000-0001-6405-6351

Faculdade São Leopoldo Mandic, Brazil E-mail: pripriandrade@yahoo.com.br

Ademir Franco

ORCID: https://orcid.org/0000-0002-1417-2781 Faculdade São Leopoldo Mandic, Brazil E-mail: ademir.junior@slmandic.edu.br

Luciana Butini Oliveira

ORCID: https://orcid.org/0000-0002-8755-6540 Faculdade São Leopoldo Mandic, Brazil E-mail: luciana.oliveira@ slmandic.edu.br Carlos Augusto Souza-Lima ORCID: https://orcid.org/0000-0002-6014-006X Faculdade São Leopoldo Mandic, Brazil E-mail: carlos.lima@slmandic.com.br José Luiz Cintra Junqueira ORCID: https://orcid.org/0000-0001-6788-4021 Faculdade São Leopoldo Mandic, Brazil E-mail: jose.luiz@slmandic.edu.br

Mariana Rosa Merendi Lopes Cavalette ORCID: https://orcid.org/0000-0003-2931-3695 Faculdade São Leopoldo Mandic, Brazil E-mail: mariana@iro.com.br Anne Caroline Costa Oenning ORCID: https://orcid.org/0000-0001-9731-8629 Faculdade São Leopoldo Mandic, Brazil E-mail: anne.oenning@slmandic.edu.br

\begin{abstract}
This study revisited three oral radiology centers (ORC) and screened the main clinical indications that justified the request for cone-beam computed tomography (CBCT) examination in Endodontics. The databases of three ORCs were searched for requests of CBCT exams taken for Endodontic purposes over the last two years. The extracted data consisted of the total number of CBCT exams, the clinical indication in the endodontic field that justified the CBCT exam, the outcome of each exam (from the report of Oral Radiologists), and demographic data of the patients. From the total CBCT exams $(n=4,583)$, nearly $13 \%(n=611)$ were taken for Endodontic purposes. Most of the clinical indications were related to root fractures $(65 \%)$ and periapical lesions/disease (24.1\%). Radiologists' reports hypothesized more often toward periapical lesion/disease $(70.5 \%)$, root fracture $(51.4 \%)$ and accidents/complications $(25.2 \%)$. Some clinical indications significantly varied based on age. In particular, post-traumatic imaging and the investigation of root resorption were more common in young patients, while the prevalence of exams for the investigation of pulpal calcifications and root fractures increased with age. More interestingly, there was a significant disagreement between the clinical indication that justified the CBCT examinations and the outcomes retrieved from radiologists' reports $(\mathrm{p}<0.005)$. This study illustrates the broad spectrum of CBCT applications for the diagnosis, treatment planning and follow-up in Endodontics. Attention is necessary to the disagreements between clinical indications and imaging outcomes, especially because certain conditions in the routine Endodontics are only visible with the aid of advanced tools.
\end{abstract}

Keywords: Endodontics; Imaging; Radiology; Cone beam computed tomography. 


\section{Resumo}

O presente estudo revisitou três centros de radiologia odontológica (ORC) e rastreou as principais indicações clínicas que justificaram a solicitação do exame de tomografia computadorizada de feixe cônico (TCFC) em Endodontia. Os bancos de dados de três ORCs foram pesquisados em busca de solicitações de exames CBCT realizados para fins endodônticos nos últimos dois anos. Os dados extraídos consistiram no número total de exames de TCFC, a indicação clínica na área endodôntica que justificou o exame de TCFC, o resultado de cada exame (a partir do laudo do Radiologista Oral) e os dados demográficos dos pacientes. Do total de exames de TCFC $(\mathrm{n}=4.583)$, quase $13 \%$ ( $\mathrm{n}=$ 611) foram feitos para fins endodônticos. A maioria das indicações clínicas foi relacionada a fraturas radiculares $(65 \%)$ e lesões / doenças periapicais $(24,1 \%)$. Os laudos dos radiologistas levantaram a hipótese mais frequentemente de lesão / doença periapical (70,5\%), fratura radicular (51,4\%) e acidentes / complicações (25,2\%). Algumas indicações clínicas variaram significativamente com base na idade. Em particular, a imagem pós-traumática e a investigação de reabsorção radicular foram mais comuns em pacientes jovens, enquanto a prevalência de exames para investigação de calcificações pulpares e fraturas radiculares aumentou com a idade. Mais curiosamente, houve uma discordância significativa entre a indicação clínica que justificou os exames de TCFC e os resultados obtidos dos relatórios dos radiologistas $(\mathrm{p}<0,005)$. Este estudo ilustra o amplo espectro de aplicações da TCFC para o diagnóstico, planejamento de tratamento e acompanhamento em Endodontia. É preciso atentar para as divergências entre as indicações clínicas e os desfechos de imagem, principalmente porque certas condições da rotina da Endodontia só são visíveis com o auxílio de ferramentas avançadas.

Palavras-chave: Endodontia; Imaginologia; Radiologia; Tomografia computadorizada de feixe cônico.

\section{Resumen}

Este estudio revisitó tres centros de radiología oral (CRO) y cribo las principales indicaciones clínicas que justificaron la solicitud de examen por tomografía computarizada de haz cónico (CBCT) en endodoncia. Se realizaron búsquedas en las bases de datos de tres CRO en busca de solicitudes de exámenes CBCT realizados con fines endodónticos durante los últimos dos años. Los datos extraídos consistieron en el número total de exámenes CBCT, la indicación clínica en el campo endodóntico que justificó el examen CBCT, el resultado de cada examen (del informe de los radiólogos orales) y los datos demográficos de los pacientes. Del total de exámenes CBCT ( $\mathrm{n}=4583)$, casi el 13\% (n = 611) se tomaron con fines de endodoncia. La mayoría de las indicaciones clínicas se relacionaron con fracturas radiculares $(65 \%)$ y lesiones / enfermedades periapicales $(24,1 \%)$. Los informes de los radiólogos plantearon con mayor frecuencia la hipótesis de lesión / enfermedad periapical (70,5\%), fractura de raíz (51,4\%) y accidentes / complicaciones $(25,2 \%)$. Algunas indicaciones clínicas variaron significativamente según la edad. En particular, las imágenes postraumáticas y la investigación de la reabsorción radicular fueron más comunes en pacientes jóvenes, mientras que la prevalencia de exámenes para la investigación de calcificaciones pulpares y fracturas radiculares aumentó con la edad. Más interesante aún, hubo un desacuerdo significativo entre la indicación clínica que justificaba los exámenes CBCT y los resultados obtenidos de los informes de los radiólogos ( $<<0,005$ ). Este estudio ilustra el amplio espectro de CBCT para el diagnóstico, la planificación del tratamiento y el seguimiento en endodoncia. Es necesario prestar atención a los desacuerdos entre las indicaciones clínicas y los resultados de las imágenes, especialmente porque ciertas condiciones en la endodoncia de rutina solo son visibles con la ayuda de herramientas avanzadas.

Palabras clave: Endodoncia; Imágenes; Radiología; Tomografía computarizada de haz cónico.

\section{Introduction}

Despite the two-dimensional visualization of roots and root canal systems, as well as the superimposition of anatomic structures, radiographic examinations are fundamental to guide endodontic treatment (Patel et al. 2010). Cone-beam computed tomography (CBCT) emerged in the last decades to overcome the limitations of conventional radiography by introducing tridimensional and multiplanar navigation for diagnostic purposes (Lo Giudice et al. 2018; Patel, et al. 2010).

The European Society of Endodontics points out specific clinical indications to justify the request for CBCT exams. Teeth with unspecific signs and symptoms, suspicious periapical lesions and inconclusive radiographic features fit within the potential indications for CBCT. Other conditions include the post-traumatic assessment of teeth, preoperative visualization of complex root canal systems, retreatment of unsuccessful procedures, management of root resorption, and surgical planning (Patel et al. 2019).

Based on the translational role of CBCT in Endodontics from diagnosis to follow-up, an important influence of the CBCT diagnostic information on clinical decision is expected (Patel et al. 2015, Krug et al. 2019). With additional and more 
detailed endodontic information, more predictable outcomes may be achieved (Ee et al. 2014). The existing protocols and recommendations established by international expert opinions for the use of CBCT in Endodontics might not reflect in the contemporary clinical practice. For this reason, surveillance and exploratory studies are necessary to find out if the recommendations are followed in practice. To the best of our knowledge, only a previous study has evaluated the use or applications of CBCT in Endodontics (Krug et al. 2019). Therefore, this study was designed with a monitoring purpose and aimed to screen the routine of oral radiology centers (ORC) to verify the main clinical indications that led to requests of CBCT examinations in the field of Endodontics. The rational and bioethical use of radiodiagnostic tools in Endodontics is discussed along the study.

\section{Methodology}

\section{Study design and ethical aspects}

This study had observational design and retrospective approach. The structure of the manuscript was presented according to pre-established scientific standards (von Elm et al. 2014). Institutional ethical approval was obtained (protocol: \#3499584).

\section{Sampling and settings}

Records of clinical requests for CBCT exams $(n=4,583)$ were revisited from three ORC of Southeast Brazil: a small private ORC, with an interval of sampling from April to November 2019; a large private ORC, sampling from June 2019 to February 2020; and a university ORC, sampling from January 2018 to December 2020. The interval of data collection was different among centers because of their inherent routine of exams and archiving protocol.

All the available records were retrospectively searched for requests with clinical justification in the field of Endodontics $(\mathrm{n}=611,13.3 \%)$. These image exams were taken from females $(\mathrm{n}=398,65.1 \%)$ and males $(\mathrm{n}=213,34.9 \%)$ aged between three and 89 years (mean age: $52 \pm 14.9$ years).

Together with the requests provided by clinicians, the reports delivered by oral radiologists were collected as well. The combination of requests and reports would enable to verify whether the clinical suspicions were confirmed by the CBCT exams. The possible diagnostic hypotheses raised by the oral radiologists were listed as follows: periapical lesion/disease, anatomic variation of roots or root canal systems, accidents/complications (e.g. fractured instruments, perforations, and incomplete obturation), post-traumatic investigation, and others (i.e. missing information in the requests and reports). Patients' demographic data, such as sex and age were registered.

\section{Statistical analysis}

Data were analyzed by means of descriptive statistics, namely absolute (n) and relative frequencies (\%). Chi-square and Fisher's exact tests were used to investigate the association of sex and the raised diagnostic hypothesis. T-tests were used to enable inferences from comparisons based on age. McNemar's test quantified the association between the clinical indication (endodontic-related) and the diagnostic hypothesis raised by the oral radiologists in their reports. All the tests were performed with R software (R Foundation for Statistical Computing, Vienna, Austria) set with statistical significance of 5\%, and confidence interval of $95 \%$. 


\section{Results}

\section{Descriptive outcomes}

The most common clinical justification behind the request for CBCT exams in Endodontics was the investigation of root fractures (65\%), followed by periapical lesion/disease (24.1\%) (Figure 1). The most prevalent diagnostic hypothesis extracted from the report of oral radiologists was the periapical lesion/disease $(70.5 \%)$, followed by root fracture (51.4\%) and accidents/complications (25.2\%) (Figure 2).

Figure 1 - Distribution of clinical indications that justified the request for cone-beam computed tomography (CBCT) for endodontic purposes.

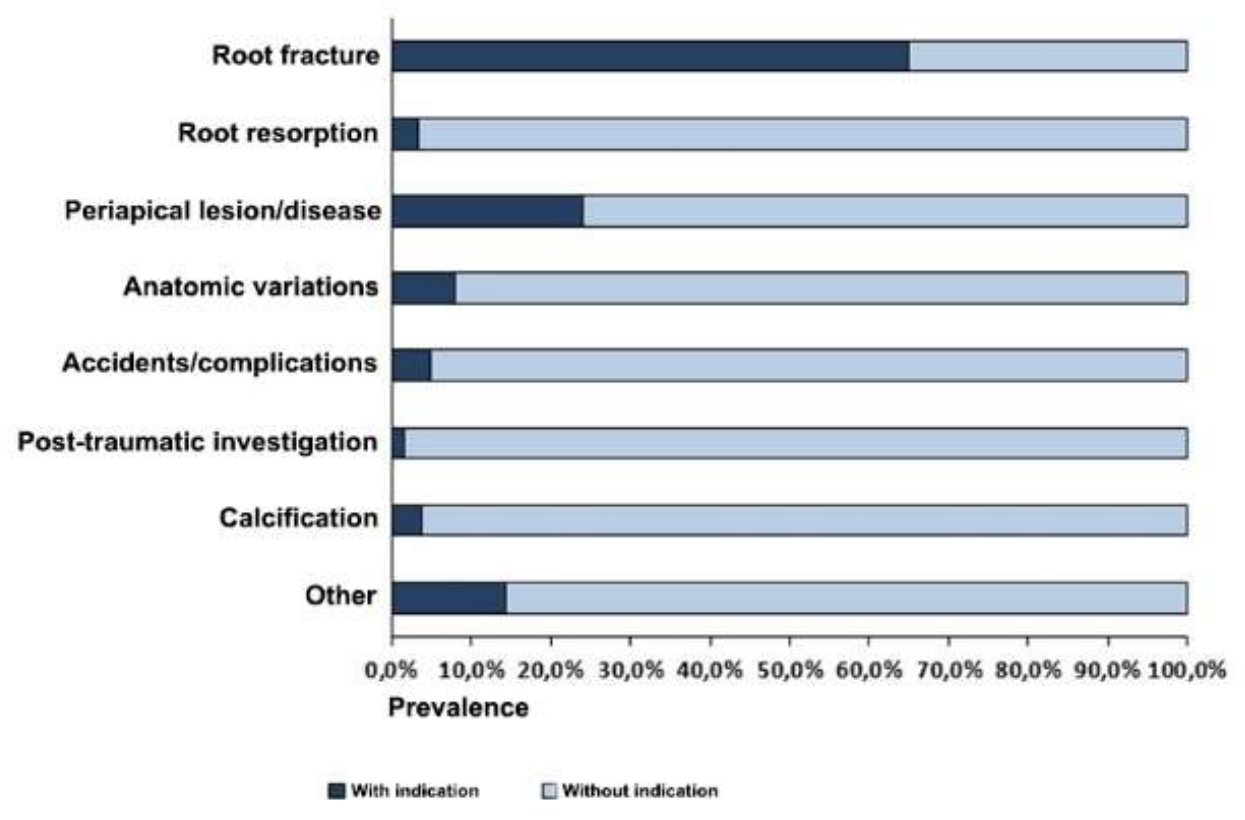

Source: Authors. 
Figure 2 - Distribution of cone-beam compute tomography (CBCT) outcomes extracted from the report of oral radiologists.

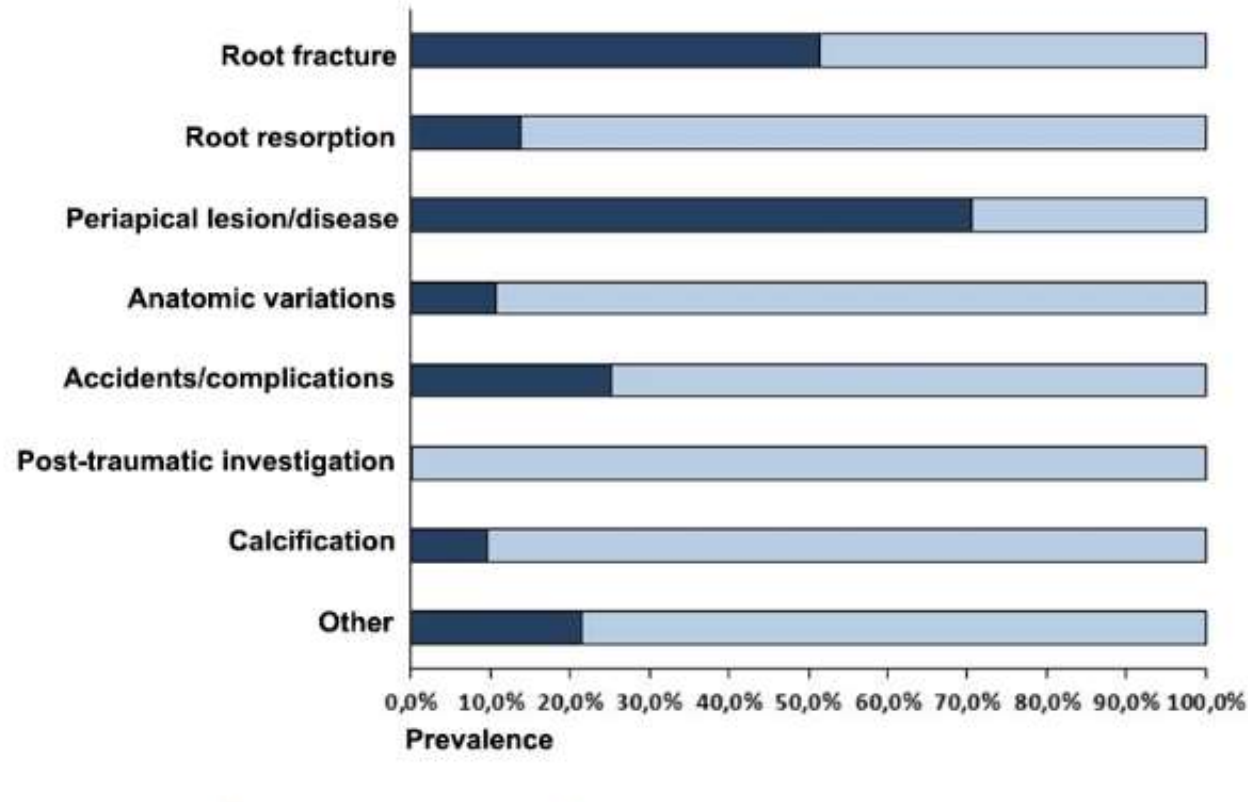

Eith report

[ Without report

Source: Authors.

\section{Association with age and sex}

Post-traumatic investigation of endodontic status figured as the most common clinical justification for CBCT exams in young individuals $(\mathrm{p}<0.05)$, while CBCT investigation of root canal calcification was most common in older individuals ( $\mathrm{p}$ $<0.05)$. According to the report of oral radiologists, root fractures were more frequent in older individuals ( $<<0.05)$. On the other hand, root resorption was more common among young individuals ( $<<0.05)$. Root fractures were more associated with males $-60.6 \%$ the male individuals presented this condition. In females, the prevalence rate decreased to $46.5 \%$ (p $<0.05$ ) (Table 1).

\section{Comparison between clinical justification and CBCT outcomes}

All the conditions suspected by the clinicians that requested CBCT exams had statistically significant disagreement with their alleged outcome from oral radiologists' reports $(\mathrm{p}<0.05)$, except for the anatomic variations of root and root canal systems (Table 2). Root fractures, in particular, had clinical indication and CBCT confirmation in $43.4 \%$ of the cases, while in 9\% of the cases the patients had root fractures but did not underwent CBCT exams for this reason. A similar trend was found for root resorption, which appeared as CBCT finding in patients (12.4\%) with no clinical suspicion. Periapical lesion/disease had clinical indication and CBCT confirmation in $18.8 \%$ of the cases, while in $51.7 \%$ of the individuals, this condition was detected via CBCT but not suspected by clinicians (Table 2). 
Research, Society and Development, v. 10, n. 1, e42910111842, 2021

(CC BY 4.0) | ISSN 2525-3409 | DOI: http://dx.doi.org/10.33448/rsd-v10i1.11842

Table 1 - Clinical indications that justified the use of CBCT for endodontic purposes and their respective outcome extracted from the report of oral radiologists.

\begin{tabular}{|c|c|c|c|c|c|c|c|c|c|c|}
\hline \multirow{4}{*}{ Condition } & \multicolumn{5}{|c|}{ Clinical indication } & \multicolumn{5}{|c|}{ Outcomes from the report of oral radiologists } \\
\hline & \multicolumn{2}{|l|}{ Sex } & \multirow[b]{3}{*}{$\mathrm{p}$} & \multirow{3}{*}{$\begin{array}{l}\text { Age } \\
\text { Mean (SD) }\end{array}$} & \multirow[b]{3}{*}{$\mathrm{p}$} & \multicolumn{2}{|l|}{ Sex } & \multirow[b]{3}{*}{$\mathrm{p}$} & \multirow{3}{*}{$\begin{array}{l}\text { Age } \\
\text { Mean (SD) }\end{array}$} & \multirow[b]{3}{*}{$\mathrm{p}$} \\
\hline & Female & Male & & & & Female & Male & & & \\
\hline & $\mathrm{n}(\%)$ & $\mathrm{n}(\%)$ & & & & $\mathrm{n}(\%)$ & $\mathrm{n}(\%)$ & & & \\
\hline Root fracture & $263(66.1 \%)$ & $134(62.9 \%)$ & ${ }^{1} 0.4338$ & $52.8(13.9)$ & 0.0960 & $185(46.5 \%)$ & $129(60.6 \%)$ & ${ }^{1} 0.0009$ & ${ }^{4} 53.6(13.6)$ & 0.0070 \\
\hline Root resorption & $10(2.5 \%)$ & $10(4.7 \%)$ & ${ }^{1} 0.1486$ & 46.7 (19.9) & 0.1059 & $55(13.8 \%)$ & $30(14.1 \%)$ & ${ }^{1} 0.9280$ & ${ }^{3} 48.6(16.6)$ & 0.0235 \\
\hline Periapical lesion/disease & $97(24.4 \%)$ & $50(23.5 \%)$ & ${ }^{1} 0.8046$ & $51.2(13.9)$ & 0.4851 & $284(71.4 \%)$ & $147(69.0 \%)$ & ${ }^{1} 0.5450$ & $52.3(14.3)$ & 0.4462 \\
\hline Anatomic variations* & $30(7.5 \%)$ & $19(8.9 \%)$ & ${ }^{1} 0.5488$ & $52.6(13.9)$ & 0.7798 & $44(11.1 \%)$ & $22(10.3 \%)$ & ${ }^{1} 0.7827$ & $49.6(15.7)$ & 0.1754 \\
\hline Accidents/complications $* *$ & $17(4.3 \%)$ & $13(6.1 \%)$ & ${ }^{1} 0.3180$ & $52.3(15.0)$ & 0.9200 & $102(25.6 \%)$ & $52(24.4 \%)$ & ${ }^{1} 0.7417$ & $53.8(15.2)$ & 0.0843 \\
\hline Post-traumatic investigation & $4(1.0 \%)$ & $5(2.4 \%)$ & ${ }^{2} 0.2887$ & ${ }^{3} 25.4(15.1)$ & $<0.0001$ & $1(0.2 \%)$ & $0(0.0 \%)$ & ${ }^{2} 1.000$ & $21(-)$ & - \\
\hline Calcification & $17(4.3 \%)$ & $6(2.8 \%)$ & ${ }^{1} 0.3681$ & ${ }^{4} 60.0(15.7)$ & 0.0089 & $40(10.0 \%)$ & $18(8.4 \%)$ & ${ }^{1} 0.5204$ & ${ }^{4} 57.1(14.9)$ & 0.0064 \\
\hline Other & $60(15.1 \%)$ & $28(13.2 \%)$ & ${ }^{1} 0.5174$ & $51.0(15.9)$ & 0.4869 & $86(21.6 \%)$ & $46(21.6 \%)$ & ${ }^{1} 0.9973$ & $50.0(15.0)$ & 0.0781 \\
\hline Total & $398(100.0 \%)$ & $213(100.0 \%)$ & & $52.0(14.9)$ & & $398(100.0 \%)$ & $213(100.0 \%)$ & & $52.0(14.9)$ & \\
\hline
\end{tabular}

${ }^{1}$ Chi-square test; Fisher's exact test ${ }^{2} ;{ }^{3} \mathrm{Age}$ significantly lower between clinical indication and outcome; ${ }^{4}$ Age significantly higher between clinical indication and outcome; *anatomic variations of roots and root canal systems; **e.g. instrument fracture and perforation. Source: Authors. 
Table 2 - Agreement between the indications (requests) and the results of the CBCT exams in Endodontic ( $\mathrm{n}=611)$.

\begin{tabular}{|c|c|c|c|c|c|}
\hline \multirow[t]{2}{*}{ Condition } & \multicolumn{2}{|c|}{ Agreement } & \multicolumn{2}{|c|}{ Disagreement } & \multirow[b]{2}{*}{ p-value } \\
\hline & $\begin{array}{l}\text { No indication, no } \\
\text { positive result }\end{array}$ & $\begin{array}{l}\text { With indication, } \\
\text { with positive result }\end{array}$ & $\begin{array}{l}\text { No indication, } \\
\text { with positive } \\
\text { result }\end{array}$ & $\begin{array}{l}\text { With indication, } \\
\text { no positive result }\end{array}$ & \\
\hline Root fracture & $159(26.0 \%)$ & $259(43.4 \%)$ & $55(9.0 \%)$ & $138(22.6 \%)$ & $<0.0001$ \\
\hline Root resorption & $515(84.3 \%)$ & $9(1.5 \%)$ & $76(12.4 \%)$ & $11(1.8 \%)$ & $<0.0001$ \\
\hline Periapical lesion/disease & $148(24.2 \%)$ & $115(18.8 \%)$ & $316(51.7 \%)$ & $32(5.2 \%)$ & $<0.0001$ \\
\hline Anatomic variations* & $512(83.8 \%)$ & $16(2.6 \%)$ & $50(8.2 \%)$ & $33(5.4 \%)$ & 0.0620 \\
\hline Accidents/complications** & $445(72.8 \%)$ & $18(3.0 \%)$ & $136(22.3 \%)$ & $12(2.0 \%)$ & $<0.0001$ \\
\hline Post-traumatic investigation & $601(98.5 \%)$ & $0(0.0 \%)$ & $1(0.2 \%)$ & $9(1.5 \%)$ & 0.0114 \\
\hline Calcification & $546(89.4 \%)$ & $16(2.6 \%)$ & $42(6.9 \%)$ & $7(1.2 \%)$ & $<0.0001$ \\
\hline Other & $418(68.4 \%)$ & $27(4.4 \%)$ & $105(17.2 \%)$ & $61(10.0 \%)$ & 0.0006 \\
\hline
\end{tabular}

${ }^{1} \mathrm{McNemar} *$ anatomic variations of roots and root canal systems; **e.g. instrument fracture and perforation. Source: Authors.

\section{Discussion}

This study revisited the CBCT databases of three ORC from Southeast Brazil between 2018 and 2020. Endodonticrelated imaging exams represented $611(13.3 \%)$ of the total sample (4,583). Despite the several advantages of CBCT imaging for pre-, trans- and postoperative endodontic procedures (Fayad et al. 2015, Patel et al. 2010), the discrete amount of endodontic clinical indications behind the requests for CBCT exams might be justified by the more common use of bidimensional radiographs. Other reasons for the not so expressive frequency of endodontic indications include the cost (biological and financial) vs. benefit relation potentially weighted by clinicians before requesting or not CBCT exams. It is important to note, however, that the restricted use of CBCT follows the guidelines of international associations dedicated to establish best practices in (oral) radiology - especially when it comes to avoiding CBCT in less complex cases (Fayad et al. 2015; Oenning et al. 2018; Patel et al. 2019).

Conversely, complex cases figure as potential targets for the use of CBCT in Endodontics. Root fractures, for instance, represented $65 \%$ of the total requests for endodontic-related CBCT exams. Currently, CBCT is well-known for its valuable diagnostic performance on the investigation of root fractures (Yiit 2010, Brady et al. 2014, Venskutonis et al. 2014).This task, however, is challenging because the fractures may be very small (Venskutonis et al. 2014, Brady et al. 2014). Additionally, some dental materials, such as metallic post and core and gutta-percha, might hamper the visualization of root fractures because of the inherent artifact formation (Patel et al. 20192, Verner et al. 2017). Other authors also highlight that when CBCT is used to investigate root fractures there is higher change of dental extraction (Rodríguez et al. 2017). The present study revealed that $22.6 \%$ of the sampled individuals had clinical indication for the investigation of root fracture through CBCT, but the condition was not confirmed after the imaging exam. More importantly, 9\% of the patients were examined with CBCT for other reasons and revealed root fractures. The idea of root fracture being false positive or negative is 
dangerous from a clinical perspective because they eventually indicate that conditions that directly affect patients' health have been overlooked or overestimated.

Depending on the severity, root resorption may be difficult to detect in bidimensional image exams because of the superimposition of dental and maxillofacial structures ( $\mathrm{Li}$ et al. 2019). This type of condition may spread in different directions and dental tissues and the inherent radiolucency from mineral loss is not always detected in radiographs (Venskutonis et al. 2014). CBCT emerges again as a tool for optimal visualization (Ee et al. 2014). Out of the 20 cases suspected of root resorption, nearly half had CBCT confirmation of the hypothesis. This finding corroborated the valuable of role and impact of CBCT for the diagnosis and treatment plan of root resorption (Lo Giudice et al. 2018, Viana et al. 2020). Further outcomes of this study revealed that in 76 cases root resorption was an incidental finding. This phenomenon may rely on the several circumstances with which root resorption is associated, such as close relation with impacted teeth (Li et al. 2019), dental trauma (Van Acker et al. 2016) and periapical lesions (Venskutonis et al. 2014). All these circumstances may show root resorption as secondary finding. Consequently, the records of each ORC might not include root resorption as main clinical indication for CBCT - so the resorption is diagnosed incidentally.

Apical periodontitis is the most common disease that might result from endodontic infection. Periapical lesion/diseases in early stage may not be visible in plain radiographs, because bone destruction is usually minimal or even superimposed with adjacent anatomic structures (Patel et al. 20192). This is the point where CBCT emerges as an alternative. In the present study, CBCT confirmed 115 cases of periapical lesion/disease out of 147 suspicions. The incidental detection of these images (without previous suspicion), on the other hand, accounted for 316 cases. This outcome raise a flag to clinicians by showing that some dental diseases may progress silently and only detectable with more advanced imaging modalities. It is worth mentioning, however, that a considerable part of those small radiolucencies (radiographically undetectable) may not have any clinical implication.

Anatomic variations were investigated in this study because of their importance on the diagnosis and prognosis of endodontic cases. In this context, $\mathrm{CBCT}$ is known for its contribution to the identification of supernumerary roots and canals (Lo Giudice et al. 2018, Patel et al. 2019; Patel et al. 20192, Fayad et al. 2015). According to the present findings, fifty cases (8.2\%) depicted a kind of anatomic variation detected via CBCT without a previous clinical request (suspicion). This phenomenon possibly relies on the fact that some anatomic variations of endodontic interest mimic conditions that are usually referred for СВСТ exam, such as periapical lesion/diseases and root fractures. From a clinical perspective, the anatomic variations may be involved in several intercurrences in Endodontics. Dilaceration, for instance, may lead to root perforation (transoperative - accident) (Verner et al. 2017), while overlooked additional canals may lead to a recurrent infection (postoperative - complication). Accordingly, this study also assessed the frequency of exams requested for suspected intercurrences. Unsuspected intercurrences figured as the second most common outcome from the comparison between clinical suspicion and imaging examination. Suspected intercurrences with CBCT confirmation also appeared. These findings confirm the usefulness of СBCT exams as source of evidence to exclude or point out malpractice related to endodontic procedures.

When age merged into the equation, it revealed stronger associations between young individuals and the clinical request for post-traumatic $\mathrm{CBCT}$, and older individuals and the clinical request to the visualization of pulpal calcification via CBCT. These outcomes corroborate the scientific literature that shows facial trauma with the involvement of maxillary anterior teeth more predominantly in children and adolescents (Gallichan et al. 2020). Similarly, secondary dentin apposition occurs during life leading to a higher chance of pulpal calcification in adults and the elderly (Goga et al. 2008).

A limitation inherent to radiologic observational studies with retrospective sampling is setting the collection of images within the exact same period. The three ORCs investigated work with distinct protocols for the storage of data. Despite the eventual limitation, this study did not aim to compare different ORCs, but was designed to combine the endodontic casuistic in 
the interface with oral radiology in order to draw stronger conclusions.

\section{Conclusion}

Despite the clear usefulness of $\mathrm{CBCT}$ in the Endodontic practice highlighted in the present study, plain radiographs remain fundamental to guide clinical decisions toward the request for more complex imaging or not. The justification of CBCT for Endodontics is guided by international associations that release technical reports that are constantly reviewed and updated (SEDENTEX et al. 2011). Based on the guidelines, CBCT use must consider case-specific indication and protocols to be justified prior to clinical procedures in Endodontics.

\section{Acknowledgments}

This study was financed in part by the Coordenação de Aperfeiçoamento de Pessoal de Nível Superior - Brasil (CAPES) - Finance Code 001. The authors deny any conflicts of interest related to this study.

\section{References}

Brady, E., Mannocci, F., Brown, J., Wilson, R., \& Patel, S. A. (2014). Comparison of cone beam computed tomography and periapical radiography for the detection of vertical root fractures in nonendodontically treated teeth. Int Endod J, 47, 735-746. http://doi.org/10.1111/iej.12209

Ee, J., Fayad, M. I., \& Johnson, B. R. (2014). Comparison of endodontic diagnosis and treatment planning decisions using cone-beam volumetric tomography versus periapical radiography. J Endod, 40, 910-916. http://doi.org/10.1016/j.joen.2014.03.002

Fayad, M. I., Nair, M., Levin, M. D., et al. (2015). AAE and AAOMR Joint Position Statement Use of Cone Beam Computed Tomography in Endodontics 2015 Update. Oral Surg Oral Med Oral Pathol Oral Radiol, 120, 508-12. http://doi.org/10.1016/j.000o.2015.07.033

Gallichan, N., Albadri, S., Dixon, C., \& Jorgenson, K. (2020). Trends in CBCT current practice within three UK paediatric dental departments. Eur Arch Paediatr Dent, 21, 537-542. http://doi.org/10.1007/s40368-020-00526-w

Goga, R., Chandler, N. P., \& Oginni, A. O. (2008). Pulp stones: a review. Int Endod J, 41, 457-468. http://doi.org/10.1111/j.1365-2591.2008.01374.x

Krug, R., Connert, T., Beinicke, A., et al. (2019). When and how do endodontic specialists use cone-beam computed tomography? Aust Endod J, 45, 365-372. http://doi.org/10.1111/aej.12337

Li, D., Tao, Y., Zhang W. C. M., Zhang, X., Hu, X. (2019). External root resorption in maxillary and mandibular second molars associated with impacted third molars: a cone-beam computed tomographic study. Clin Oral Investig, 23, 4195-4203. http://doi.org/10.1007/s00784-019-02859-3

Lo Giudice, R., Nicita, F., Puleio, F., et al. (2018). Accuracy of periapical radiography and CBCT in endodontic evaluation. Int J Dent, 2514243, http://doi.org/10.1155/2018/2514243

Oenning, A. C., Jacobs, R., Pauwels, R., Stratis, A., Hedesiu, M., \& Salmon, B. (2018). Cone-beam CT in paediatric dentistry: DIMITRA project position statement. Pediatr Radiol, 48, 308-316. http://doi.org/10.1007/s00247-017-4012-9

Patel, S., Kanagasingam, S., \& Mannocci, F. (2010). Cone beam computed tomography (CBCT) in endodontics. Dent Update, 37, 373-379. https://doi.org/10.12968/denu.2010.37.6.373

Patel, S., Durack, C., Abella, F., Shemesh, H., Roig, M., \& Lemberg, K. (2015). Cone beam computed tomography in Endodontics - a review. Int Endod J, 48, 3-15. http://doi.org/10.1111/iej.12270

Patel, S., Brown, J., Pimentel, T., Kelly, R. D., Abella, F., \& Durack, C. (2019). Cone beam computed tomography in Endodontics - a review of the literature. Int Endod J, 52, 1138-52. http://doi.org/10.1111/iej.13115

Patel, S., Brown, J., Semper, M., Abella, F., \& Mannocci, F. (2019). European Society of Endodontology position statement: Use of cone beam computed tomography in Endodontics: European Society of Endodontology (ESE) developed by. Int Endod J, 52, 1675-1678. http://doi.org/10.1111/iej.13187

Rodríguez, G., Abella, F., Durán-Sindreu, F., Patel, S., \& Roig, M. (2017). Influence of cone-beam computed tomography in clinical decision making among specialists. J Endod, 43, 194-199. http://doi.org/10.1016/j.joen.2016.10.012

SEDENTEX CT Project, Sezgin, O. S., Kayipmaz, S., Yasar, D., Yilmaz, A., \& Ozturk, M. H. (2011). Comparative dosimetry of dental cone beam computed tomography, panoramic radiography, and multislice computed tomography. Oral Radiology, 28, 32-37. http://doi.org/10.1007/s11282-011-0078-5

Van Acker, J. W. G., Martens, L. C., \& Aps, J. K. M. (2016). Cone-beam computed tomography in pediatric dentistry, a retrospective observational study. Clin Oral Investig, 20, 1003-1010. http://doi.org/10.1007/s00784-015-1592-3 
Research, Society and Development, v. 10, n. 1, e42910111842, 2021

(CC BY 4.0) | ISSN 2525-3409 | DOI: http://dx.doi.org/10.33448/rsd-v10i1.11842

Venskutonis, T., Plotino, G., Juodzbalys, G., \& Mickevičiene, L. (2014). The importance of cone-beam computed tomography in the management of endodontic problems: A review of the literature. J Endod, 40, 1895-18901. http://doi.org/10.1016/j.joen.2014.05.009

Verner, F. S., D’Addazio, P. S., Campos, C. N., Devito, K. L., Almeida, S. M., \& Junqueira, R. B. (2017). Influence of Cone-Beam Computed Tomography filters on diagnosis of simulated endodontic complications. Int Endod J, 50, 1089-1096. http://doi.org/10.1111/iej.12732

Viana, W. A. M., Montagner, F., Vieira, H. T., Dias da Silveira, H. L., Arús, N. A., \& Vizzotto, M. B. (2020). Can cone-beam computed tomography change endodontists' level of confidence in diagnosis and treatment planning? A before and after study. J Endod, 46, 283-238. http://doi.org/10.1016/j.joen.2019.10.021

Von Elm, E., Altman, D. G., Egger, M., et al. (2014). The Strengthening the Reporting of Observational Studies in Epidemiology (STROBE) Statement: guidelines for reporting observational studies. Int J Surg, 12, 1495-1499. http://doi.org/10.1136/bmj.39335.541782.AD

Ozer, S. Y. (2010). Detection of vertical root fractures of different thicknesses in endodontically enlarged teeth by cone beam computed tomography versus digital radiography. $J$ Endod, 36, 1245-1249. http://doi.org/10.1016/j.joen.2010.03.021 